\title{
Jarosław i Anna Iwaszkiewiczowie, Jerzy Lisowski, Listy 1947-1979, Wydawnictwo Akademickie Sedno, Warszawa 2020, ss. 1168
}

„Listy Dionizosa”, „korona dotychczasowych publikacji Iwaszkiewiczowskich dokumentów osobistych" ${ }^{1}$, to tylko wybrane $\mathrm{z}$ haseł firmujących korespondencję pomiędzy małżeństwem Iwaszkiewiczów a tłumaczem pisarza Jerzym Lisowskim. Dwutomowy zbiór wydany pod koniec grudnia 2020 roku stanowi korpus epistolarny rozległych rozmiarów, pełen emocji i cennych informacji o życiu korespondentów. Przy okazji jego niedawnej premiery warto zastanowić się nad tym, co może wnieść do współczesnej recepcji postaci Iwaszkiewicza? Czym różni się od innych, opublikowanych wcześniej, bloków jego korespondencji? Ponadto: jak modelowane są w nim epistolarne związki nadawczo-odbiorcze?

\section{O zawartości wydania Listów 1947-1979}

Tom I przedstawia rozkwit fascynującej przyjaźni pomiędzy mężczyznami: na początku homoerotycznej, platonicznej, później przeradzającej się w trwałą relację zawodową. Opisy uczuć i wspomnienia z podróży mieszają się z mnogością nawiązań do kultury francuskiej, dzieł literatury europejskiej autorstwa Franza Kafki, Alberta Camusa czy Jeana-Paula Sartre'a. Listy pełne są więc cytatów z innych dzieł i porównań osób znanych piszącym z życia codziennego do postaci z literatury. Część korpusu listów poświęcona zapewnieniom

1 Mowa o recenzjach: J. Strzałka, Listy Dionizosa. Anna i Jarostaw Iwaszkiewiczowie, Jerzy Lisowski: Listy. Tom I 1947-1952, Tom II 1953-1979, „Polityka”, wydanie internetowe z 12 stycznia 2021, www.polityka.pl/tygodnikpolityka/kultura/ksiazki/2097851,1,recenzja-ksiazki-agnieszka-i-robert-papiescy-anna-ijaroslaw-iwaszkiewiczowie-jerzy-lisowski-listy.read?fbclid=IwAR0AfniTuwWsOQtvvxJdjf6r9ZJP49QmD QVCLA97mCAzMDLIZ_75nZaL3cE [dostęp: 16.03.2021], oraz: R. Romaniuk, Proteusz z ulicy Wiejskiej, „Twórczość” 2021, nr 2, s. 131. 
korespondentów o wspólnym uczuciu przybliża czytelnikom pogłębione autoanalizy emocjonalne Iwaszkiewicza, przedstawiające go jako mężczyznę samotnego, egocentrycznego, namiętnego, oddanego. Zdecydowanie jednym z ciekawszych aspektów tego tomu jest intensywność prowadzonej korespondencji, tworzonej codziennie i z wielkim zaangażowaniem, zgodnie z twierdzeniem Stefanii Skwarczyńskiej o listach, które „pisze się z życia, na gorąco" ${ }^{2}$. Faktycznie, wymiany wiadomości są niemal natychmiastowe, choć nieraz jednak rozmijają się geograficznie (adresaci zmieniają miejsca zamieszkiwania).

Tom II stanowi z kolei cenne świadectwo powojennego życia literackiego. Czytelnik listów zapoznaje się z opisami gwaru panującego w redakcji „Twórczości” (konkurującej wówczas z „Nową Kulturą”); odnajduje w nich również barwne opisy postaci związanych z tym czasopismem (Juliana Stryjkowskiego, Henryka Berezy). Druga część zbioru koncentruje się na życiu domowym w Stawisku, przedstawiając funkcjonowanie Iwaszkiewicza pomiędzy czasem spędzonym z wnukami i zajmowaniem się chorym przyjacielem Jerzym Błeszyńskim.

\section{Wobec pochłaniającej osobowości}

Dużą wartością Listów... jest możliwość obserwacji ewolucji charakterów korespondentów. Na początku zbioru Iwaszkiewicz „młodnieje” w kontakcie z Lisowskim, który to zwraca się do niego per „Mistrzu” (s. 145). Wówczas obaj przeżywają fascynację literaturą francuską i sobą nawzajem. Jednak w dalszych częściach epistolografii dochodzi do odwrócenia ról: to Lisowski więcej czerpie z energii Iwaszkiewicza, stając się dojrzalszy, nie bojąc się krytykować swojego autorytetu i ograniczając zwierzenia. W tomie II Iwaszkiewicz już nie czyni młodszemu ojcowskich uwag („naiwność Twoja nie zna granic”, s. 206) — to raczej Lisowski coraz częściej wytyka starszemu przyjacielowi błędy („wiersz [...] nieudany, niegodny Ciebie - nie powinieneś go drukować”, t. II, s. 5).

Wydanie korespondencji Iwaszkiewicza ukazuje jego „pochłaniające” oblicze, można powiedzieć - za Robertem Papieskim — „dionizyjskie”. Listy są bowiem dla pisarza pożywką do długofalowego oddziaływania na swój własny wizerunek (autokreacja) oraz, poprzez stosowanie napomnień, na postać swojego adresata. Można powiedzieć, że w tym właśnie zbiorze epistolarnym performatywna wartość listu (czyli kreująca, wpływająca na rzeczywistość, jak ujęła to Brigitte Diaz ${ }^{3}$ ) spotyka się z jego dyskursywnością. Epistolografia staje się miejscem już nie tylko rozmowy, ale prowokacją do ciągłych odniesień i wytwarzania obrazu samego siebie w tekście. Fenomen ten można zaobserwować zwłaszcza w „środkowej” fazie trwania relacji mężczyzn, kiedy ich listy rozmijają się ze sobą (adresaci zmieniają miejsca pobytu), a obieg komunikatu — jak w cyceroniańskiej genezie listu — staje się „mową do nieobecnego", więc „mówieniem do” zamiast „mówieniem z”.

Choć większość recenzji Listów... koncentruje się na postaci Iwaszkiewicza, warto przy lekturze skupić się na nie mniej ważnej postaci Lisowskiego, objawiającego w listach swoją niezwykle silną osobowość. Tłumacz pisarza nie poddaje się Iwaszkiewiczowi: błyskotliwie, z kulturą i klasą odpiera jego złośliwości i osobiste aluzje. Tym, czym wyróżniają się omawiane listy wśród innych korespondencji Iwaszkiewicza, jest umiejętność stawiania granic przez jego adresata. Lisowski nie ulega swojemu rozmówcy i werbalnie oddziela swoje sprawy pry-

2 Zob. S. Skwarczyńska: Teoria listu, Lwów 1937, s. 15.

3 B. Diaz: L'Épislolaire ou la pensée nomade. Formes et fonctions de la correspondance dans quelques parcours d'écrivains au XIX siècle, Paris 2002, s. 49-62; cyt. za: E. Rybicka: Antropologiczne i komunikacyjne aspekty dyskursu epistolograficznego, „Teksty Drugie” 2004, nr 4, s. 43-44. 
watne od absorbującej współpracy z literatem. Przy tym można zaobserwować, jak trudno jest uwolnić się od relacji zależności - tworzonej przez Iwaszkiewicza przecież głównie w korespondencji. Ostatecznie spotkania mężczyzn (przynajmniej w tomie I) są bowiem nieliczne, a jednak czytelnik ma wrażenie intensywnego kontaktu korespondentów, ciągłego ruchu, generowanego głównie przez pisarza. Stanowi to kontrast do innych wydanych zbiorów korespondencji pisarza; choć listy do Błeszyńskiego pozostawione są bez odpowiedzi, w przypadku epistolografii z żoną, córkami czy przybranym synem da się zauważyć ciągłą walkę o wyartykułowanie głosu odbiorcy Iwaszkiewicza. Na tym tle listy do Lisowskiego to rozmowa (najbardziej) wyrównana, niezdominowana przez jedną ze stron.

W każdym liście korespondenci starają się zaprezentować siebie od innej, nowej strony raz próbując się emocjonalnie odsłonić, raz skryć za pancerzem ironii, profesjonalizmu, wyliczeń detali z życia domowego. Tym bardziej warto się przyjrzeć głosowi Lisowskiego, piszącego w zupełnie innym stylu niż Iwaszkiewicz. O ile twórca Panien zWilka ma w zwyczaju przesyłać (nawet co dwa dni) kilkustronicowe epistoły z opisami nastrojów, o tyle jego tłumacz nie daje się sprowokować do gry zwierzeń; jego odpowiedzi są konkretne, regularne, asertywne - lecz wciąż emocjonalne.

\section{Trzecia bohaterka?}

Zestawienie Iwaszkiewicza z mocnym głosem Lisowskiego miejscami strąca pisarza z piedestału „mistrza” oraz kwestionuje jego decyzje zawodowe. Pokazuje również, jak niezwykłą osobowością był tłumacz pisarza, zasadniczo organizujący zarówno życie redakcji „Twórczości”, jak i sprawy przekładów utworów literata. Czy jednak korpus tej epistolografii można nazwać w jakiś sposób „przełomowym”?

Choć głównym tematem wydanej korespondencji jest interakcja pomiędzy pisarzem a jego współpracownikiem, nie należy zapominać o trzeciej bohaterce wymiany listów Annie Iwaszkiewicz. Mimo że jej imię zostało umieszczone na stronie tytułowej, w zbiorze liczącym czterysta dwanaście listów zawarto jedynie jej osiem krótkich wiadomości. Krytycy literaccy łatwo przeszli do porządku dziennego nad jej nieobecnością, jednak myślę, że przypadek ten wymaga rozważenia. Patrząc pod tym kątem, wydaje się, że Listy... nie mają charakteru "wyzwalającego": nie mówią o "odrębności broniącej się przed zagarnięciem przez dyskurs dominujący”, nie są „archiwami gromadzącymi głosy podporządkowanych”, o których pisze Anna Pekaniec w swojej wizji współczesnych autobiograficznych odczytań listów ${ }^{4}$. Gdzie w tej korespondencji jest więc miejsce Anny Iwaszkiewicz?

Z odpowiedziami na jej wiadomości albo zwlekano, albo jej listy nie trafiały pod aktualny adres adresata. Sposobem na dotarcie do Anny Iwaszkiewicz było z kolei wysłanie listu do pisarza i polecenie mu, żeby przeczytał go żonie (co nie zdarzało się zawsze). Czy zatem warto było umieszczać jej imię w tytule wydania?

O ile wybór ten jest efektem uczciwości edytorskiej (potrzeba odnotowania istnienia jej listów), a nie czystej kurtuazji, stanowi bardzo ważny sygnał dla czytelników. Mianowicie można powiedzieć, iż Anna Iwaszkiewicz funkcjonuje w tej epistolografii poprzez swoją nieobecność. Jest punktem odniesienia w rozmowach mężczyzn, ale rzadko ma głos. Choć jej imię promuje okładkę, tłumaczka egzystuje bardziej w przestrzeni przypisów, marginaliów,

4 Por. A. Pekaniec: Autobiografie i epistolografia w perspektywie kulturowej teorii literatury [w:] Polonistyka na poczatku XX wieku. Diagnozy, koncepcje, perspektywy, T. 1, red. R. Cudak, K. Pospiszil, Katowice 2018, s. 256. 
aniżeli głównych kart listów. Warto przy tym zaryzykować tezę, że można ją traktować jako ogólną reprezentację postaci kobiecych w listach Iwaszkiewicza i Lisowskiego - kobiety są tam muzami, punktami odniesień, powierniczkami lub przedmiotami żartów i anegdot. Kiedy nie pełnią tych funkcji, nie istnieją.

\section{Podsumowanie}

Czytając listy twórcy Brzeziny i jego tłumacza, łatwo można dać się pochłonąć pasjonującym dyskusjom mężczyzn, mającym zresztą wybitną wartość merytoryczną i edytorską. Jest to lektura angażująca od początku do końca, zaskakująca co stronę różnymi (często nieznanymi) obliczami korespondentów, ich uczuciami, opisami zmian w polskim i francuskim życiu literackim. Zdecydowanie stanowi wyjątkową pozycję bibliograficzną w kontekście badań nad Iwaszkiewiczem (i Lisowskim), uzupełniając wiele nieznanych faktów z jego życia i twórczości.

Edycję listów przygotowano z pietyzmem, dbając o redakcję oraz staranne opracowanie przypisów (zajmujących imponującą część zbioru). Dzięki znakomitemu rozeznaniu Roberta i Agnieszki Papieskich w życiu, twórczości i archiwaliach Iwaszkiewicza, czytelnik zapoznający się z listami do Lisowskiego śledzi równocześnie losy polskiej historii i kultury literackiej XX wieku. W tym znaczeniu epistolografia Iwaszkiewiczów stanowi coś więcej niż prywatną wymianę zdań z tłumaczem pisarza: jest to źródło wiedzy historycznej, biograficznej i literackiej, zapis życia jednej z najbardziej rozpoznawalnych postaci ubiegłego wieku.

Warto jednak pamiętać o drugiej, alternatywnej historii rozwijanej na kartach tej korespondencji - będącej świadectwem pomijania głosu kobiet w kulturze i literaturze. 